\title{
GEOÉTICA E RELAÇÕES INTERNACIONAIS
}

\section{GEOÉTICA AND INTERNATIONAL RELATIONS}

\author{
Alberto Pereira dos Santos \\ Professor Adjunto da UERJ-IGEOG-DTUR \\ albertopsantos@usp.br
}

\begin{abstract}
Resumo
Este artigo é fruto de nossos estudos de doutorado em geografia política/humana na Universidade de São Paulo. A primeira parte do artigo tenta discutir o embate entre dois conceitos que estão no bojo da geografia política e das relações internacionais "segurança ambiental" e "realismo político", buscando dialogar com as ideias de alguns autores contemporâneos que defendem o paradigma ambiental como alternativo neste século XXI. A segunda parte do artigo trata-se de uma introdução à "Geoética do apoio mútuo" que defendemos como uma nova epistemologia ontológica engendrada a partir da pesquisa que constatou, de um lado, a existência das geopolíticas das igrejas no território brasileiro e, de outro lado, a ausência de governo das igrejas sobre o processo de mutação das religiosidades, sobretudo um processo de emancipação espiritual através do crescimento da população sem religião que desenvolve a religiosidade com autonomia e tem preocupação em "salvação" ou conservação do mesmo e único templo da humanidade, a Terra.
\end{abstract}

\section{Palavras chaves:}

Geoética, realismo político, segurança ambiental, espiritualidade, relações internacionais.

\begin{abstract}
This article is the result of our doctoral studies in human/political geography at the University of São Paulo. The first part of the article attempts to discuss the clash between two concepts that are in the peak of political geography and international relations "environmental security" and "political realism", seeking dialogue with the ideas of some contemporaries authors who defend the environmental paradigm as an alternative in the 21st century. The second part of the article is an introduction to "Geoética of mutual support" that we advocate as a new ontological epistemology engendered from the search that found, on the one hand, the existence of geopolitics of churches in Brazilian territory and, on the other hand, the absence of government churches about the process of mutation of religiosities, especially a process spiritual emancipation through growth of the population without religion that develops the religiosity with autonomy and have concern in "salvation" or conservation of the same and only temple of humanity, the Earth.
\end{abstract}

Geo UERJ - Ano 14, nº. 23, v. 2, $2^{\circ}$ semestre de 2012 p. 479-508

ISSN: 1415-7543 E-ISSN: 1981-9021

http://www.e-publicacoes.uerj.br/index.php/geouerj 
Key Words: Geoética, political realism, environmental security, spirituality, international relations.

\section{Introdução}

A questão ambiental se tornou tema de discussão nas relações internacionais, pelo menos, desde 1972, na Conferência de Estocolmo, Suécia. Duas décadas depois, na II Conferência Mundial sobre Meio Ambiente e Desenvolvimento, a Rio 92, as Nações Unidas deliberaram assumir compromissos para o futuro como, por exemplo, a Agenda 21.

Na Rio+20, em 2012, novamente as Nações Unidas debateram a questão ambiental, porém, embora tenha havido alguns avanços, nós humanos, a humanidade como um todo, teremos ainda que dar grandes saltos em matéria de mudança de comportamento para garantir a segurança ambiental a longo prazo (RIBEIRO, 2001), isto é, que as políticas implementadas pelos governos dos Estados nacionais sejam, de fato, menos imediatistas uma vez que supostamente estariam defendendo os "interesses nacionais" segundo o realismo político (MORGENTHAU, 2003) como paradigma de Relações Internacionais.

Em outro nível de discussão, no microespaço da sala de aula, no processo de formação de educadores e gestores ambientais, às vezes nos deparamos com certo ceticismo, ou pelos menos com o enfraquecimento da utopia necessária para se refletir, debater e praticar educação e gestão ambiental. Algumas perguntas nos foram colocadas na sala de aula por estudantes de graduação e pós-graduação como, por exemplo, "se os governantes sabem da necessidade de conservar os recursos naturais, por que eles agem de forma contrária?", ou ainda, "se a educação ambiental já se tornou uma lei nacional no Brasil, por que muitas prefeituras ainda não a implantaram no âmbito de sua gestão, especialmente através das secretarias de educação e de meio ambiente?”.

São questionamentos que, de um lado, revelam, em parte, preocupação dos educadores e gestores ambientais em processo de formação e, de outro lado, nos estimulam à reflexão. Nesse sentido, entendemos como necessário analisar a questão ambiental a partir de várias dimensões, e não apenas por meio de uma visão somente

Geo UERJ - Ano 14, nº 23 , v. 2, $2^{\circ}$ semestre de 2012 p. 479-508 ISSN: 1415-7543 E-ISSN: 1981-9021

http://www.e-publicacoes.uerj.br/index.php/geouerj 
biológica e/ou pedagógica. Sem levarmos em conta a dimensão política, a análise da questão ambiental seria fragmentada, parcial. Contudo, a discussão política, sobretudo pelo viés do realismo político, a nosso ver, não exclui a ética necessária para o enfrentamento da crise ambiental. Assim sendo, indagamos: a Geoética, isso, seria utopia?

Sabemos da amplitude do tema em tela e também das limitações do presente texto. Nosso objetivo, porém, neste sucinto artigo busca, de um lado, refletir sobre a relação entre os conceitos "segurança ambiental" e "realismo político" e, de outro lado, introduzir o que entendemos por "geoética". Assim sendo, este artigo se insere como uma pequena contribuição da geografia política/humana para a reflexão e o debate no tocante à dimensão política na gestão e na educação ambiental, bem como da dimensão ética da crise ambiental no cenário das relações internacionais.

A ideia de Geoética foi inicialmente engendrada a partir das reflexões e das atividades de campo quando ministrei, entre 2007 e 2010, a disciplina Educação Ambiental: Histórico e Concepções Filosóficas num curso de Pós-graduação em Educação Ambiental numa Universidade particular na Grande São Paulo. Aproveito aqui para agradecer aos estudantes com os quais pude realizar entrevistas e auscultar suas visões acerca das relações entre suas crenças religiosas (islâmicos, budistas, católicos, evangélicos, espíritas e sem religião) e a questão ambiental.

O presente artigo está dividido em duas partes. Na primeira parte tenta-se discutir o embate entre dois conceitos que estão no bojo da geografia política e das relações internacionais, a saber, "segurança ambiental" (RIBEIRO, 2001; LE PRESTE, 2003) e "realismo político" (MORGENTHAU, 2003). Busca-se dialogar com as ideias de alguns autores contemporâneos que defendem o paradigma ambiental como alternativo nas relações internacionais neste século XXI. Nesse sentido, por um lado, constata-se a bipolarização conceitual e certo reducionismo cartesiano ao se tratar da crise ambiental, especialmente em política de gestão e de educação ambiental e, por outro lado, concorda-se com alguns autores que sugerem um olhar pautado na complexidade (MORIN, 2005; CASTORIADIS \& COHN-BENDIT, 1981; GONÇALVES, 1989), algo que nos possibilita pensar na construção de uma nova epistemologia e ontologia da questão ambiental.

Geo UERJ - Ano 14, no. 23, v. 2, $2^{\circ}$ semestre de 2012 p. 479-508 ISSN: 1415-7543 E-ISSN: 1981-9021 http://www.e-publicacoes.uerj.br/index.php/geouerj 
A segunda parte do artigo trata-se de uma introdução à "Geoética do apoio mútuo" que defendemos em nosso doutorado em geografia humana como uma nova epistemologia ontológica engendrada a partir da pesquisa que constatou, de um lado, a existência das geopolíticas das igrejas no território brasileiro e, de outro lado, a ausência de governo das igrejas sobre o processo de mutação das religiosidades, sobretudo um processo de emancipação espiritual através do crescimento da população sem religião que desenvolve a religiosidade com autonomia e tem preocupação em "salvação", ou melhor, com a conservação do mesmo e único templo da humanidade, a Terra.

Entendemos que as duas partes do artigo se articulam e se complementam, na medida em que a primeira faz a discussão teórica e prática, demonstrando o paradoxo entre, de um lado, a necessidade de segurança ambiental e, de outro, a prevalência do realismo político nas ações de governos desde a escala internacional até a escala nacional e municipal. Se o realismo político, enquanto paradigma de relações internacionais ainda é válido e aplicado pelos Estados, admitem-se também outros paradigmas nas teorias de Relações Internacionais como, por exemplo, o construtivismo e a teoria crítica articulada com outras visões de mundo. (SARFATI, 2005).

Para o físico Fritjof Capra (1984) a crise ambiental contemporânea traz, na essência, uma profunda consciência espiritual. Nesse sentido, a segunda parte do artigo se articula com a primeira na medida em que explicita o que se entende por geoética do apoio mútuo como contribuição para a teoria das Relações Internacionais, uma vez que defende a cooperação entre todas as religiosidades das populações (budistas, hinduístas, cristãs e islâmicas) que se preocupam com a crise ambiental. A Geoética fundamenta-se a partir do pensamento complexo (MORIN, 2005), buscando dialogar com algumas ideias da Física Quântica (CAPRA, 1984, 1994; GOSWAMI, 2006) e, em certa medida, resgatando algumas ideias filosóficas do período Pré-Socrático (BORNHEIM, 1985), bem como algumas ideias da ética aristotélica. (ARISTÓTELES, 2007)

Se a consciência ambiental é, na essência, uma profunda consciência espiritual (CAPRA, 1984), acredita-se que a cooperação entre as diversas expressões de religiosidades das populações religiosas possibilitam refletir e construir caminhos para o fortalecimento da política internacional das Nações Unidas explicitada pela criação da Aliança de Civilizações. Preocupada com o acirramento de conflitos de civilizações

Geo UERJ - Ano 14, no. 23, v. 2, $2^{\circ}$ semestre de 2012 p. $479-508$

ISSN: 1415-7543 E-ISSN: 1981-9021

http://www.e-publicacoes.uerj.br/index.php/geouerj 
após o atentado terrorista de 11 de setembro de 2001, a ONU (Organizações das Nações Unidas), através de seu Secretário Geral, Kofi Annan, formalizou em 14 de julho de 2005 a criação da Aliança de Civilizações. Essa iniciativa tem caráter permanente e natureza preventiva, cujo Terceiro Fórum Mundial ocorreu em 2010, no Rio de Janeiro (ONU, 2011).

\title{
Segurança Ambiental, Realismo Político e a questão socioambiental.
}

É possível garantir segurança ambiental diante do realismo político?

Esta questão nos instiga a registrar, aqui, alguns apontamentos que são frutos das leituras, da reflexão e dos debates na pós-graduação na Universidade de São Paulo. ${ }^{i}$ Tentaremos refletir sobre a questão levantada acima nesta primeira parte do artigo, buscando dialogar com as ideias de alguns autores contemporâneos. Pela natureza deste artigo, não se pretende esgotar o assunto, ou dar conta da questão levantada de forma acabada. Contudo, pode-se pensar numa reflexão crítica que introduza algumas ideias minimamente pertinentes ao tema em tela.

Em primeiro lugar, nunca é demais estabelecer uma mínima definição dos conceitos inseridos na abordagem deste sucinto texto, ou seja, o que se entende por "segurança ambiental" e "realismo político"? Esses dois conceitos estão no cerne teórico da Geografia Política e da Teoria de Relações Internacionais.

Segundo Le Preste (2003, p. 411) “a segurança ambiental é aqui entendida como a proteção do meio ambiente a longo prazo. A ONU utiliza amplamente o conceito neste sentido e fala de segurança das espécies ou da atmosfera."

Mas podemos aprofundar o entendimento do conceito segurança ambiental concebendo-o como a garantia da "base material" de recursos necessários à reprodução da vida no planeta. Nas palavras do geógrafo Wagner Costa (RIBEIRO, 2001, p.109) o conceito de segurança ambiental:

\begin{abstract}
nos faz refletir sobre a necessidade de manter as condições da reprodução da vida humana na Terra, posto que ainda não se tem notícia da existência de outro planeta com condições naturais semelhantes ao que habitamos, não deixando outra alternativa senão aqui vivermos. Em síntese, a Terra ainda é a morada da espécie humana - ao menos por enquanto.
\end{abstract}

Por sua vez, o conceito realismo político tem sua origem teórica nas ideias de pensadores clássicos da ciência política como Maquiavel (na obra $O$ Príncipe), e

Geo UERJ - Ano 14, nº 23, v. 2, $2^{\circ}$ semestre de 2012 p. 479-508

ISSN: 1415-7543 E-ISSN: 1981-9021

http://www.e-publicacoes.uerj.br/index.php/geouerj 
Hobbes (na obra Leviatã). Segundo Morgenthau (2003, p.18): “O realismo político é governado por leis objetivas que têm raízes na natureza humana. (...) O realismo admite que a ideia de interesse é realmente a essência da política e que não é afetada pelas circunstâncias de tempo e de lugar".

Ora, o Estado - este dragão indomável e mal necessário contra o "homem que é o lobo do homem" -, na visão hobbesiana, tem seus interesses a defender, mas os indivíduos, as pessoas também têm interesses particulares, calcados em determinadas visões de mundo, que legitimam, em certa medida, as ações do Estado. Nesse sentido, de forma sintética neste texto, o realismo político pode ser entendido como a defesa, em última análise, dos interesses nacionais. Mas não existe nação sem empresas, sem grupos, sem partidos, logo se deduz que além dos interesses nacionais, na base da sociedade existem os interesses corporativos (empresas, partidos, sindicatos) e interesses individuais de cada ser humano. Aliás, o homem se constitui como a fonte formadora do Estado e da guerra ou da paz mundial, como explicita Kenneth Waltz, um dos mais renomados pensadores contemporâneos de teoria das Relações Internacionais (WALTZ, 2004).

Segundo Morgenthau (2003), os estados empenham a "oposição direta” dentro de uma estrutura de equilíbrio de poder para manter, aumentar ou demonstrar seu poder, partindo do pressuposto que o mundo é um sistema internacional anárquico.

Nessa concepção, vimos no cenário político internacional, por exemplo, o governo dos Estados Unidos se recusar a assinar o Protocolo de Kyoto, contrariando quase todos os argumentos científicos de que é necessário reduzir a emissão de $\mathrm{CO}^{2}$ como prevenção ao aumento da temperatura média no planeta, o aquecimento global. Ou seja, mesmo com todos os argumentos científicos defensores do meio ambiente e a articulação do movimento ambientalista - inclusive de "minorias de ativistas" dentro dos Estados Unidos - o governo Bush optou por defender os “interesses nacionais”, isto é, prevaleceu a força do realismo político.

Frente a essa postura do governo dos Estados Unidos em relação à questão ambiental, mesmo sabendo-se que o país emite sozinho um quarto do total de $\mathrm{CO}^{2}$ produzido no mundo, caberia, talvez, questionar: Quais valores morais mais profundos sustentam o realismo político e as ideias hegemônicas da maioria da nação norte-

Geo UERJ - Ano 14, nº. 23, v. 2, $2^{\circ}$ semestre de 2012 p. $479-508$

ISSN: 1415-7543 E-ISSN: 1981-9021

http://www.e-publicacoes.uerj.br/index.php/geouerj 
americana e sustentaram o governo Bush?

No sentido de responder a essa questão, destaca-se da obra "Saber Ambiental" as palavras de Leff (2001, p.83):

\begin{abstract}
As doutrinas econômicas são construídas - de maneira explícita ou implícita - sobre teorias e pressupostos morais. Uma indagação sobre a natureza e a causa da riqueza das nações de Adam Smith segue sua Teoria dos sentimentos morais, e Weber viu o espírito do capitalismo na ética do protestantismo. A racionalidade econômica fundou-se no pressuposto de agentes econômicos que, conduzidos por uma 'mão invisível', traduzem suas condutas egoístas num bem comum; e a ética do trabalho, a frugalidade e a poupança estiveram associadas à reinversão de lucros e excedentes para acelerar a acumulação do capital.
\end{abstract}

Essa questão abre a possibilidade para se pensar que o realismo político se aplica não apenas na esfera das relações internacionais, dos governos nacionais (federal, estadual e municipal), mas também na esfera das empresas, do capital privado e, até em certa medida, na base dos interesses das pessoas, dos indivíduos fundamentados em determinados valores morais.

Da forma como está exposto, esse embate teórico e prático que coloca a segurança ambiental, de um lado, e o realismo político, de outro, poder-se-ia pensar que a humanidade estaria se assemelhando a um "cachorro correndo a traz de seu rabo", ou talvez estivesse enrascada nos labirintos das encruzilhadas dogmáticas maniqueístas (ou religiosas).

Ou seja, sabe-se que é urgente reduzir e eliminar os depósitos de lixo urbano e proteger as áreas de mananciais, sob o risco de se contaminar os lençóis freáticos; sabese que é necessário reduzir a poluição atmosférica, sob o risco de aumento das mortes por doenças respiratórias advindas da poluição do ar; enfim, sabe-se que a segurança ambiental (global, nacional e local) deve ser prioridade para a garantia das condições de vida na Terra. No entanto, governos, empresas e pessoas acabam optando pela defesa dos interesses políticos, das vantagens imediatas, cujo emblema é o consumismo do supérfluo e a posse de bens materiais a qualquer preço.

Diante da globalização econômica, construída filosoficamente com base no paradigma cartesiano, que tem causado a degradação ambiental desigualmente em escala global, a segurança ambiental surge como um paradigma alternativo a esse estado de coisas.

Geo UERJ - Ano 14, no. 23, v. 2, $2^{\circ}$ semestre de 2012 p. $479-508$

ISSN: 1415-7543 E-ISSN: 1981-9021

http://www.e-publicacoes.uerj.br/index.php/geouerj 
Nas palavras de Dabelko (apud: CANO, 1998, p.31): "El concepto de seguridad medioambiental, en sus múltiples variantes, representa un paradigma alternativo para ordenar y para enfrentarse a ciertas amenazas en el mundo cada vez más interdependiente y com um medio ambiente cada vez más degradado de la post-Guerra Fria".

Contudo, o paradigma alternativo da segurança ambiental não resolve a totalidade da crise ambiental. Por quê? Segundo as análises de Javier Cano (1998), pode-se destacar os seguintes problemas:

1) o conflito ambiental potencial apresenta variáveis de conflitos antecedentes e intervenções de tipo social e político (etnicidade, classe social, estruturas religiosas, etc,)

2) tanto a construção teórica da segurança como os instrumentos práticos para garantir essa segurança estão demasiadamente identificados com a orientação estadista e militarista.

3) tenderia como consequiência a militarização do movimento ambientalista em lugar do efeito esperado de "verdear" a segurança.

4) ainda persiste um grau importante de incerteza científica.

O contexto de incerteza e contradição parece se ampliar na medida em que se considera que vivemos numa sociedade de risco (GARCIA-TORNEL, 2001, p.11): “un riesgo no es lo mismo que una catástrofe. Riesgo es una situación que implica peligro y que, ocasionalmente, puede tener desenlace catastrófico o no tenerlo”.

Ou seja, catástrofe é um acidente natural como, por exemplo, o caso do maremoto no Oceano Indico, responsável pelo Tsunami na Ásia, em 26 de dezembro de 2004, que causou a morte de mais de 300 mil pessoas. O risco, por sua vez, é uma situação de perigo que pode ser evitado, desde que previamente se tome as devidas precauções.

Catástrofes naturais, como terremotos, maremotos, furacões etc, fogem ao controle humano. Contudo, suas consequências podem ser amenizadas. No caso do Tsunami na Ásia, em 2004, o número de mortes poderia ter sido menor, desde que os governos dos países atingidos tivessem tomado as devidas precauções, como a instalação de sistema de segurança monitorado para alerta à população. Desde 1994,

Geo UERJ - Ano 14, nº. 23, v. 2, $2^{\circ}$ semestre de 2012 p. $479-508$

ISSN: 1415-7543 E-ISSN: 1981-9021

http://www.e-publicacoes.uerj.br/index.php/geouerj 
numa Conferência Internacional em Tóquio, os cientistas haviam afirmado que Tsunamis poderiam ocorrer na região do Oceano Índico. No entanto, o realismo político predominou sobre a cabeça dos governos daqueles países, negligenciando os investimentos necessários à instalação de sistema de monitoramento de tsunamis, isto é, na segurança ambiental.

Constata-se que, de modo geral, o realismo político tem prevalecido sobre a segurança ambiental. Posto desse modo poder-se-ia pensar, equivocadamente, que o realismo político representaria o "mal" e a segurança ambiental seria o "bem". Ora, esse naipe de maniqueísmo não convém numa análise racional. Aliás, a racionalidade judaico-cristã foi responsável, em grande medida, pelo massacre da natureza.

Segundo Leff (2001, p.86):

A civilização judeu-cristã, com sua pretensa superioridade do homem sobre os demais seres vivos, gerou um processo de dominação da natureza através da ciência. A racionalidade capitalista se construiu em torno de uma doutrina econômica que aspira a uma cientificidade fundada numa racionalidade formal e em sua eficácia técnica, cada vez mais afastadas da subjetividade $e$ dos valores, o que levou à superexploração de recursos e ao desequilíbrio dos ecossistemas naturais.

A crítica à razão técnica ocidental, ao paradigma cartesiano, parece ser um ponto de convergência entre vários pensadores críticos ocidentais das mais diversas opções filosóficas ou concepções de mundo, em especial quando o objetivo é desmontar o paradigma cartesiano e construir outro mundo possível sustentável fundado no paradigma ecológico e numa ética ambiental.

Nesse sentido, destacam-se, a seguir, as palavras do teólogo crítico Leonardo Boff (1996, p.46) que analisa os termos "subjugar e dominar" contido no livro Gênesis:

As palavras 'subjugar e dominar' foram lidas no contexto da modernidade. Elas foram assumidas literalmente. Daí se entendeu a missão do ser humano como Descartes e Bacon bem o disseram: um dominador e escravizador das forças na natureza para o benefício individual e social. Essa interpretação legitimava, com força da Palavra de Deus, o saque que a Terra sofreu e vem sofrendo. Precisamos rever essa compreensão e resgatar o sentido originário, profundamente ecológico da mensagem bíblica.

Contudo, segundo Guattari (1993, p.53), “o relato da gênese bíblica está sendo substituído pelos novos relatos da re-criação permanente do mundo".

Se o embate segurança ambiental versus realismo político não deve ser visto como maniqueísmo, é porque essa luta pertence ao reino da humanidade, aqui em baixo, na superfície da Terra, e não ao outro mundo, ao além. Já não são mais tanto os acidentes Geo UERJ - Ano 14, nº 23 , v. 2, $2^{\circ}$ semestre de 2012 p. 479-508

ISSN: 1415-7543 E-ISSN: 1981-9021

http://www.e-publicacoes.uerj.br/index.php/geouerj 
naturais que amedrontam o ser humano - mesmo sabendo-se que eles existem e podem ser detectados pela tecnologia, como é o caso dos terremotos, furacões e até mesmo possíveis choques de corpos celestes com nosso planeta como, por exemplo, um Asteróide que, segundo probabilidades astronômicas, poderia colidir com a Terra em 2014 -, mas o que nos incomoda mais é o fato do ser humano viver, relativamente sem medo ou talvez acomodado, sem precaução, numa sociedade de risco.

$\mathrm{Na}$ categoria dos riscos tecnológicos, os acidentes nucleares ou radiativos não são privilégio das sociedades ricas, ou ditas do norte, como o acidente nuclear de Chernobil (Ucrânia). No Brasil, em 1987, o acidente radiativo com o césio-137, em Goiânia, cujos efeitos provocaram a morte de 60 pessoas e mais de seis mil foram contaminadas, demonstrou claramente a vulnerabilidade do risco "tecno-nuclear" em sociedades periféricas.

A lista de riscos e acidentes seria extensa, desde os acidentes nucleares, passando pelas construções irregulares de condomínios em terrenos inadequados, chegando até a maior tragédia socioambiental da história da sociedade brasileira ocorrida na Região Serrana do estado do Rio de Janeiro, no 11 de janeiro de 2011, cujo impacto provocou a morte de mais de mil pessoas, entre os municípios de Petrópolis, Teresópolis, Nova Friburgo e outros. No entanto, o realismo político na escada do poder local prevaleceu na defesa dos interesses de grupos e partidos políticos que se mantêm no governo dos municípios citados, especialmente em Teresópolis cujas famílias das vitimas, bem como das pessoas sobreviventes até mais de um ano depois da tragédia ainda não haviam sido indenizadas pelo Poder Público.

E o perigo na sociedade de risco está presente em todos os lugares, especialmente nos grandes centros urbanos e industriais, nos "territórios em risco". Na cidade de São Paulo, por exemplo, notícias de acidentes com carretas transportando produtos químicos de alta periculosidade não são raras, especialmente nas marginais dos Rios Tietê e Pinheiros.

Contudo, há riscos também nas obras de engenharia provocadas pelo imediatismo eleitoreiro embutido no realismo político como aquele acidente na obra da Estação Pinheiro do Metrô, ocorrido em janeiro de 2007, em São Paulo, que abriu uma enorme cratera provocando o afundamento de caminhões e micro-ônibus com várias vítimas 
fatais. Sob o comando do governador Geraldo Alckmin, do Partido da Social Democracia Brasileira (PSDB), o inicio da obra foi anunciado às pressas em 2004, em pleno ano de eleições municipais, cujo candidato do governador era José Serra ( PSDB), eleito prefeito em São Paulo naquele ano. Mesmo com inúmeras denúncias na mídia de que os imóveis da região estavam sofrendo rachaduras gravíssimas, a obra foi acelerada uma vez que se pretendia inaugurá-la em 2008, coincidindo com o ano de eleições municipais.

Mas a oposição ao governo do PSDB em São Paulo, liderada pela bancada do Partido dos Trabalhadores (PT) na Assembleia Legislativa, que inicialmente defendia a abertura de CPI para investigar as causas do referido acidente nas obras do Metrô, logo mudou de opinião, isto é, tirou o time de campo. Por quê? Como o PT pretendia eleger o deputado Arlindo Chinaglia para a presidência da Câmara dos Deputados/Congresso Nacional em 2007, articularam-se acordos políticos entre PT e PSDB, entrando na pauta e na lógica do "toma lá, dá cá" o engavetamento da CPI do Metrô na Assembleia Legislativa. Outra vez os interesses partidários prevaleceram uma vez que o PT elegeu seu candidato para a presidência da Câmara dos Deputados e o governo do PSDB em São Paulo livrou-se da CPI.

Embora haja ampla aceitação do realismo político, não se pode negar seu desgaste contemporâneo no enfretamento dos problemas ambientais. Se, por um lado, o paradigma alternativo da segurança ambiental tem problema, como os apontados anteriormente, o realismo político, por sua vez, tornou-se insustentável. Além disso, o realismo político não é um determinismo absoluto. A história é dialética e a utopia não morre.

Se esse estado de coisas é insustentável, só resta aos seres humanos buscarem outros caminhos que possibilitem a sustentabilidade ambiental nas diversas escalas do espaço geográfico: global, nacional e local.

$\mathrm{Na}$ escala global "A Ordem Ambiental Internacional” (RIBEIRO, 2001) representa um subsistema mundial que está apenas começando a ser construído. Inúmeros acordos e tratados internacionais vêm sendo assinados na ONU, no sentido da construção do ordenamento jurídico e fortalecimento do direito ambiental internacional.

E nessa busca de caminhos alternativos de construção da sustentabilidade 
socioambiental, o primeiro passo a ser admitido é o pluralismo de ideias.

Pela complexidade e diversidade dos problemas podem-se identificar múltiplas visões acerca da questão ambiental.

Diante de tantos problemas socioambientais (enchentes, áreas de risco, lixo urbano, poluição atmosférica, etc) poder-se-ia objetar que, de um lado, o problema estaria na ausência de consciência por parte dos governos e, de outro, poder-se-ia argumentar que o povo não tem consciência por isso joga lixo em lugares públicos. Por sua vez, poder-se-ia argumentar que se os empresários tivessem consciência ambiental eles não produziriam mercadorias que só poluem o ambiente.

Logo, poder-se-ia pensar que o problema (e a solução) socioambiental estaria supostamente na consciência da população (cidadãos), na consciência do governo (dos políticos) e na consciência dos empresários (da indústria, do comércio e dos serviços). Se há múltiplos interesses e facetas perpassando a problemática ambiental, tentaremos esboçar um ponto de vista a esse respeito.

Primeiramente, gostaríamos de expressar, como entendemos a questão ambiental. Não se trata aqui de uma visão fragmentadora ou de um pensamento redutor como critica Morin (2005). Ao contrário, entende-se a questão socioambiental a partir do pensamento complexo. Contudo, para os objetivos deste artigo, a princípio, e de forma ilustrativa, argumentaremos que, a nosso ver, existem de modo complementar e imbricadas entre si sete dimensões na questão ambiental, a saber:

Geo UERJ - Ano 14, nº. 23, v. 2, $2^{\circ}$ semestre de 2012 p. 479-508 ISSN: 1415-7543 E-ISSN: 1981-9021 http://www.e-publicacoes.uerj.br/index.php/geouerj 


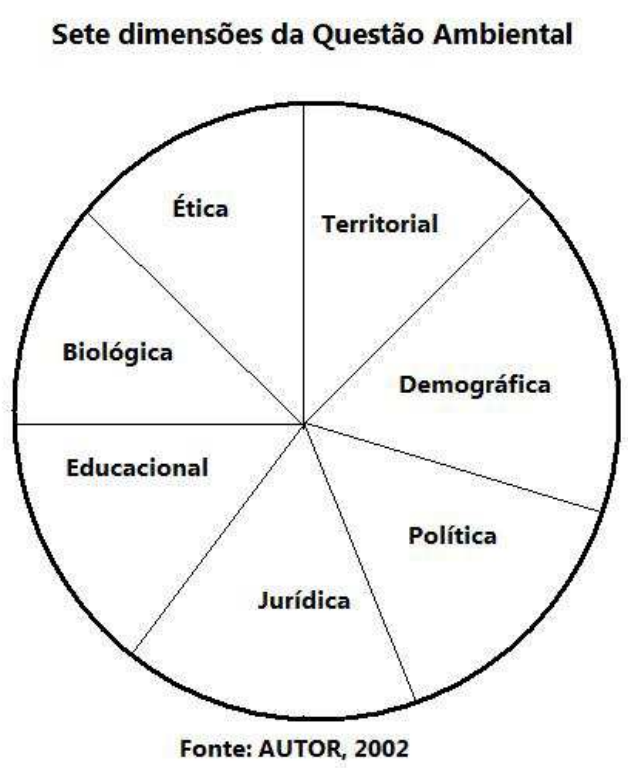

$\mathrm{Na}$ dimensão territorial insere-se a questão do limite ou da extensão da problemática ambiental que abrange do nível planetário ao nível local. Ora, se a crise ambiental é de extensão planetária, o território local parece ser o alvo mais próximo para que a população, nele habitante, consiga acertar ou enfrentar tal problema.

Existe um lema ecológico "pensamento global e ação local" que, de certo modo, sintetiza a dimensão territorial. É necessário refletir a respeito da dimensão global dos problemas ambientais. A poluição atmosférica produzida em uma determinada região industrializada pode afetar uma região rural a quilômetros de distância, por exemplo, através da chuva ácida. Por outro lado, a poluição dos córregos e riachos do nosso bairro certamente contribui para a poluição dos rios principais, matando a vida aquática (peixes e outras espécies) que ali havia.

Nesse sentido, é necessário ter a consciência global, mas a ação deve ser local, iniciando pelo território da rua onde se mora, do bairro, e assim por diante, até se atingir uma rede de ações integradas no território municipal, estadual, nacional. Existe utopia, é evidente. Mas a utopia é necessária para o nascimento do novo, de uma nova epistemologia ontológica, para a construção de um outro mundo possível.

A dimensão política refere-se ao papel do Estado enquanto poder público que tem Geo UERJ - Ano 14, no. 23, v. 2, $2^{\circ}$ semestre de 2012 p. 479-508 ISSN: 1415-7543 E-ISSN: 1981-9021 http://www.e-publicacoes.uerj.br/index.php/geouerj 
por dever, primeiro, a elaboração e gestão de políticas públicas que visem a garantia de melhores qualidade de vida de toda a população que habita um determinado território. O Estado - nos níveis municipal, estadual e federal - é governado pelos políticos profissionais (vereadores, prefeitos, deputados, governadores, senadores e presidente). Estes, na tese da democracia representativa, são eleitos pelos cidadãos como "seus representantes" para governarem (criar novas leis, cumprir a legislação em vigor e implantar políticas públicas).

A gestão ambiental (coleta seletiva, reciclagem, fiscalização veicular, despoluição e desassoreamento dos rios, plantio de árvores, ordenamento de uso e ocupação do solo, etc) compete ao Estado, enquanto estrutura de poder público. Por sua vez, aos cidadãos cabe o papel de exigir prestação de contas dos mandatos eletivos de "seus representantes". (É evidente que a democracia representativa necessita de reformas e aperfeiçoamento, mas a internet possibilita intervir através de petições públicas online).

A dimensão demográfica refere-se à questão da população, da sociedade e da necessidade de continuidade da vida social, com garantia de emprego, bem como a garantia de qualidade de vida (alimentação, saúde, etc), para todas as faixas etárias (crianças, adolescentes, adultos e idosos).

A população humana é a principal poluidora do meio ambiente. Nesse sentido, é necessário a mudança de comportamento e ações de cidadania ativa no tocante à responsabilidade que lhe cabe. A questão do consumo, por exemplo, deve ser analisada. Cada faixa etária (crianças, adolescentes, adultos e idosos) possui um nível de consumo diferente. As necessidades de uma criança ou adolescente são diferentes das necessidades de um adulto ou idoso. Quanto ao consumo por classes sociais, é importante destacar que a classe A no Brasil, por exemplo, consome cerca de quase $60 \%$ de tudo que se produz. (IBGE, 2010)

Portanto, o modelo de sociedade do consumo veiculado na mídia deve ser analisado racionalmente. Esse modelo é ambientalmente sustentável?

A dimensão educacional refere-se à necessidade do processo de formação dos estudantes e da população através da educação ambiental. Aqui entraria em ação a Educação Ambiental em todos os níveis de ensino, desde a educação infantil, passando

Geo UERJ - Ano 14, nº. 23, v. 2, $2^{\circ}$ semestre de 2012 p. 479-508 ISSN: 1415-7543 E-ISSN: 1981-9021

http://www.e-publicacoes.uerj.br/index.php/geouerj 
pelo ensino fundamental e médio, até o ensino superior. Sabe-se que o Plano Nacional de Política de Educação Ambiental no Brasil, não concebe que a educação ambiental deva ser uma disciplina específica como as que existem no currículo escolar.

A Educação Ambiental tem sido defendida como um projeto interdisciplinar de ação local em cada unidade escolar. Contudo, nem sempre tal projeto ocorre na prática. Como e por onde começar? Eis a pergunta que muitos educadores querem a resposta (de preferência mais ou menos pronta).

Mas é preciso entender que a Educação Ambiental não deve ficar circunscrita apenas à esfera da chamada educação formal ou no sistema de ensino público e privado. A realidade tem evidenciado que a Educação Ambiental tem sido praticada como projeto interdisciplinar nas inúmeras Organizações Não-governamentais (ONG’s), que, por sinal, muitas vezes dão mais certo do que alguns projetos no sistema público e/ou privado. É claro que não se pode generalizar, uma vez que existem alguns projetos bem sucedidos na rede pública. Porém, o sucesso de certos projetos de educação ambiental na rede pública, de modo geral, tem muito mais a ver com as iniciativas de alguns professores engajados na questão ambiental e menos com ações dos governos através das secretarias de educação e meio ambiente.

A dimensão jurídica refere-se ao direito ambiental, às leis de crimes ambientais. A dimensão jurídica da questão ambiental está presente em diversos níveis ou esfera do Estado, municipal, estadual e federal. Mas desde, pelo menos, 1900, quando a Coroa inglesa realizou uma reunião internacional (Inglaterra, Alemanha, Bélgica, França, Itália e Portugal) para estabelecer os limites da caça esportiva e matança indiscriminada de animais e pássaros nas colônias africanas, os Estados-nações vêm construindo uma Ordem Ambiental Internacional. (RIBEIRO, 2001, p.54)

De 1900 em diante, os acordos internacionais foram evoluindo conforme a problemática ambiental foi se tornando cada vez mais grave com consequências internacionais como, por exemplo, o Protocolo de Kyoto, assinado em 1997, para redução de emissão de gás carbônico $\left(\mathrm{C}^{2}\right)$ principal responsável pelo aumento de temperatura no planeta com consequente aquecimento global.

No Brasil o Direito Ambiental vem evoluindo e uma nova conquista foi a Lei de

Geo UERJ - Ano 14, nº. 23, v. 2, $2^{\circ}$ semestre de 2012 p. 479-508 ISSN: 1415-7543 E-ISSN: 1981-9021

http://www.e-publicacoes.uerj.br/index.php/geouerj 
Crimes Ambientais, aprovada no Congresso Nacional em 1998. Essa lei se aplica tanto para os casos de crimes ambientais que envolvam pessoas física e jurídica, quanto para os casos de crimes ambientais provocados pelos gestores públicos (prefeitos, governadores, presidentes).

A dimensão biológica refere-se à relação entre a vida humana e a vida não humana (fauna e fauna). Tem a ver com a maneira que a espécie humana se relaciona com as outras espécies animais e vegetais. Nos reinos da natureza (mineral, vegetal e animal) existe um equilíbrio.

Segundo a teoria de Gaia, o planeta Terra seria um gigantesco e complexo organismo vivo (LOVELOCK, 1996). Nesse complexo ecossistema a lei de conservação e lei de destruição atuam de forma natural através da cadeia alimentar. Contudo, a ação humana pautada na mentalidade antropocêntrica provocou a destruição abusiva responsável pelo desequilíbrio do ecossistema planetário.

Por que existem, em média, cerca de cinco camundongos para cada habitante na cidade de São Paulo com seus mais de 11 milhões de pessoas? Será ecológico, saudável, dar milho aos bombos nas praças públicas?

A água, elemento vital, para a continuidade da vida na Terra, corre o risco de contaminação até mesmo no lençol freático. De cada dez rios brasileiros, sete estão poluídos. Portanto, é necessário o ser humano refletir a respeito do uso da água e de todos os demais recursos naturais. Medidas simples, porém importantes, como o uso racional da água (redução de tempo de banho no chuveiro, a reutilização da água para lavar quintal, etc.) podem e devem ser praticadas pelos adultos e ensinadas às crianças. $\mathrm{Na}$ atualidade existe uma verdadeira geopolítica da água. (RIBEIRO, 2008)

A dimensão ética-cultural, ou dimensão cultural (LE PRESTE, 2003, p. 480) se insere na questão ambiental na medida em que se admite que a relação do ser humano com a natureza é heterogênea, ou seja, essa relação se dá, relativamente, segundo as concepções de mundo das diversas culturas.

Certamente, os valores da cultura hinduísta são diferentes dos valores da cultura ocidental; assim como os valores dos povos indígenas são diferentes dos valores dos povos dos grandes centros urbanos. Portanto, a relação homem-natureza será diversa e Geo UERJ - Ano 14, nº 23 , v. 2, $2^{\circ}$ semestre de 2012 p. 479-508 ISSN: 1415-7543 E-ISSN: 1981-9021 http://www.e-publicacoes.uerj.br/index.php/geouerj 
plural. Isso significa que a cultura e visão de mundo ocidental tem sido o lastro moral que sugere como os humanos se relacionam entre si e como estes se relacionam com a natureza. Ou seja, na concepção da moral capitalista tudo no mundo é ou pode ser mercadoria.

Contrariamente à moral capitalista, a visão de uma ambientalista hindu sugere o resgate da sacralidade da Natureza, como podemos constatar nas palavras de Vandana Shiva (2003, p.111):

\begin{abstract}
No plano social, os valores da biodiversidade em diferentes contextos culturais precisam ser reconhecidos. Os bosques sagrados, as sementes sagradas, as espécies sagradas têm sido meios culturais de tratar a biodiversidade como algo inviolável e nos dão os melhores exemplos de preservação. Além disso, precisamos reconhecer que o valor de mercado e o valor em dólares são apenas valores limitados e muitas vezes perniciosos à biodiversidade. A biodiversidade tem outros valores, como o de prover sustento e significado, e esses valores não precisam ser tratados como subordinados e secundários aos valores de mercado.
\end{abstract}

Se na dimensão da cultura, por sua diversidade, a questão ambiental não encontra um ponto onde se possa indicar superação dos conflitos socioambientais, parece-nos que a espécie Homo sapiens precisa dar um salto histórico que o coloque num campo onde se possa refletir sobre a possibilidade de uma Ética da Terra.

Nesse sentido, a nosso ver, necessário será enveredar pelo campo da filosofia e da psicologia, entras outras ciências, buscando encontrar algum caminho para uma nova epistemologia existencial. Isso nos direciona ao campo da ecologia mental, uma vez que negar a dimensão espiritual do ser humano numa abordagem de ética ambiental seria insistir no reducionismo e na fragmentação do conhecimento, o que caracterizou o cientificismo positivista. Afinal, a noosfera - a esfera das coisas do espírito, dos mitos, das crenças, dos deuses -, existe desde o alvorecer da humanidade (MORIN, 2005, p. 28).

Assim sendo, partindo para a segunda parte deste artigo, buscaremos discutir introdutoriamente o que estamos denominando como Geoética.

\title{
Por uma Geoética do apoio mútuo
}

Geo UERJ - Ano 14, nº. 23, v. 2, $2^{\circ}$ semestre de 2012 p. $479-508$

ISSN: 1415-7543 E-ISSN: 1981-9021

http://www.e-publicacoes.uerj.br/index.php/geouerj 
A geoética resgata o ideal de "apoio mútuo", filosofia proposta pelo geógrafo Piotr Kropotkin (KROPOTKIN, 2009). No lugar da geopolítica das igrejas que fomente a rivalidade entre as populações religiosas, propõe-se o "apoio mútuo", a cooperação entre todas as religiosidades em prol do enfrentamento da crise socioambiental planetária.

Antes de avançar nos argumentos acerca do que propusemos como segunda parte deste artigo vale lembrar que a geoética do apoio mútuo diz respeito a nossa proposta de síntese da tese da geopolítica das igrejas e anarquia religiosa no Brasil. Ou seja, nossa pesquisa além de investigar e constatar, de um lado, as rivalidades de poderes e influências e o expansionismo religioso das igrejas no território brasileiro e, de outro, um processo lento e fecundo de emancipação espiritual através do crescimento da população sem religião (embora com religiosidades), auscultamos também como as populações religiosas (católicas, evangélicas, espíritas, etc) pensam a respeito da crise ambiental contemporânea.

Nesse sentido, indagamos: diante da atual crise ambiental como as espiritualidades dos humanos poderiam contribuir para a sustentabilidade da Terra? Qual é a relação entre espiritualidade e a crise ambiental?

No contexto sociocultural do fim do século XX, dentre tantos fatos, constatou-se o retorno às religiões. Uma das causas dessa revalorização da religiosidade tem sido a fragilidade do ser humano perante as contradições e conflitos deste mundo, sobretudo a destruição da natureza, que põe em xeque os valores da civilização humana. Em última análise, a crise ambiental aponta para os limites da vida humana. Diante desse dilema, isto é, da destruição da vida humana (parte integrante da natureza), as pessoas procuram, também, refúgio nas religiões. É na religião, principalmente, que o ser humano encontra a possibilidade, a esperança e a fé na salvação, senão do corpo, pelo menos da alma.

A luta em defesa do meio ambiente é, na verdade, uma luta em prol da própria vida. A crise ecológica reflete o dilema da vida. Ou, em outras palavras, como sugere Castoriadis (1981, p.24): “O que está em jogo no movimento ecológico é toda a concepção, toda a posição das relações entre a humanidade e o mundo e, finalmente, a

Geo UERJ - Ano 14, nº 23, v. 2, $2^{\circ}$ semestre de 2012 p. 479-508 ISSN: 1415-7543 E-ISSN: 1981-9021

http://www.e-publicacoes.uerj.br/index.php/geouerj 
questão central e eterna: o que é a vida humana? Vivemos para fazer o quê?"

O sistema socioeconômico, as relações internacionais, o modo de vida, as relações entre as pessoas, enfim, os valores humanos, tudo está em crise. E, historicamente, é em contexto de crise que surgem mudanças, propostas alternativas, experiências que buscam, na essência, regenerar a sociedade, o mundo.

Segundo o físico Fritjof Capra a consciência ecológica é, na essência, consciência espiritual. Em suas palavras (CAPRA, 1984, p.242):

\begin{abstract}
Em última análise, essa profunda consciência ecológica é consciência espiritual. Quando o conceito de espírito humano é entendido como o modo de consciência em que o indivíduo se sente ligado ao cosmo como um todo, fica claro que a percepção ecológica é espiritual em sua essência mais profunda, e então não é surpreendente o fato de que a nova visão da realidade esteja em harmonia com as concepções das tradições espirituais”
\end{abstract}

A partir da visão de Capra (1984), auscultamos as populações religiosas (católicas, evangélicas, espíritas, sem religião, etc), cujas respostas nas entrevistas possibilitaram identificar relações entre religiosidade e preocupação ambiental.

Nas entrevistas colocamos a seguinte pergunta: "Em sua opinião, sua opção religiosa contribui para estimular sua consciência e preocupação em relação aos problemas ambientais? Justifique."

Pelas limitações deste artigo não poderemos aprofundar o tema e expor todas as respostas. Destacaremos, porém, algumas respostas como forma que exemplificação de que as populações religiosas explicitam, de seu modo, preocupação ambiental.

Segunda uma mulher evangélica da igreja batista: "Sim. Fomos ensinados que somos mordomos deste mundo constituído por Deus e devemos conserva-lo, para gerações futuras e que por estes atos seremos cobrados por Ele"

Por sua vez, uma mulher da igreja metodista respondeu o seguinte:

\begin{abstract}
Sim, na comunidade a qual frequento além do ensinamento bíblico, são abordados vários assuntos objetivando o envolvimento da comunidade tanto em ações para com o nosso próximo quanto para com a natureza (preservação do meio ambiente). Acreditamos que tudo o que Deus fez é bom e temos que fazer bom uso de tudo, pois um dia iremos prestar conta até pela má administração dos bens naturais concedidos pelo PAI.
\end{abstract}

Para uma mulher católica praticante, como se declarou, existe sim preocupação ambiental a partir de sua religião. Em suas palavras: "Sim, pois estamos em Deus e é Ele que nos ajuda com tudo isso. A preocupação ambiental é algo inevitável porque Geo UERJ - Ano 14, no 23 , v. 2, $2^{\circ}$ semestre de 2012 p. 479-508 ISSN: 1415-7543 E-ISSN: 1981-9021 http://www.e-publicacoes.uerj.br/index.php/geouerj 
aprendemos a respeitar ao próximo e ao meio ambiente em que vivemos."

$\mathrm{Na}$ visão da população espírita, a destruição da natureza revela o caráter consumista e materialista da humanidade. A degradação do meio ambiente, porém, está inserida na lei do progresso e na lei de causa e efeito. Isso se justifica pela própria categoria de mundo que habitamos, isto é, a Terra ainda é um mundo de expiação $e$ provas e por isso há tantas contradições, conflitos e sofrimentos. A maioria da humanidade terrena ainda estaria, segundo a visão espírita, muito presa aos bens materiais em detrimento dos bens espirituais.

Os espíritas, contudo, são otimistas e acreditam que tudo está em evolução: o ser humano estaria em processo de aprendizagem, a humanidade estaria evoluindo, pois teria passado do estado de barbárie à civilização material e desta passaria à civilização moral. Por isso, o grau atual de destruição da natureza seria um dos sinais de transição para um mundo de regeneração.

A partir da visão de Capra (1984), Castoriadis (1981), Boff (1996), Morin (2005) entre outros pensadores contemporâneos buscou-se relacionar as visões das religiosidades e a questão ambiental. Nesse sentido, procurou-se refletir acerca de uma ética ambiental.

Pensar sobre uma Ética da Terra, em plena conjuntura de globalização perversa, de tirania do dinheiro - como escreveu o geógrafo Milton Santos (SANTOS, 2000) -, revela-se certo romantismo, dirão alguns críticos, ou, no mínimo, certa dose de utopia.

É complexo falar a respeito de utopia, especialmente quando o universo cultural de nossa sociedade está carregado de senso comum. Nesse sentido, contrapondo-se, seria utopia acreditar que a humanidade irá, irreversivelmente, continuar trilhando essa trincheira de destruição da natureza (os seres humanos inclusive, uma vez que também somos natureza).

Mas entendemos utopia como a gestação do novo, embora o velho esteja presente, porém, numa relação dialética segundo o pensamento de Boaventura de Souza (SANTOS, 1996, p.323), quando afirma que:

A utopia é a exploração de novas possibilidades e vontades humanas, por via da oposição da imaginação à necessidade do que existe, só porque existe, em nome de algo radicalmente melhor que a humanidade tem direito de desejar e porque merece a pena lutar. A utopia é, assim, duplamente relativa. Por um lado, é chamada a atenção para o que não existe como (contra)parte integrante, mas silenciada, do que existe. Pertence à época pelo modo como

Geo UERJ - Ano 14, no. 23, v. 2, $2^{\circ}$ semestre de 2012 p. 479-508

ISSN: 1415-7543 E-ISSN: 1981-9021

http://www.e-publicacoes.uerj.br/index.php/geouerj 
se aparta dela. Por outro lado, a utopia é sempre desigualmente utópica, na medida em que a imaginação do novo é composta em parte por novas combinações e novas escalas do que existe. Uma compreensão profunda da realidade é assim essencial ao exercício da utopia, condição para que a radicalidade da imaginação não colida com o seu realismo.

Pensamos que há necessidade cultural de se construir uma Geoética. Com esta nova palavra pretendemos contribuir para a reflexão sobre uma ética ambiental, ou uma Ética da Terra, para além da bioética, neologismo proposto por Van Potter, médico oncologista norte-americano, no início da década de 1970, quando estava preocupado com os limites éticos das pesquisas na medicina. (HOSSNE, 2004, p. 192)

Nossa preocupação, enquanto geógrafo, ou simplesmente terráqueo (humano que habita o planeta Terra), pode parecer, de inicio, fantasia. Mas, para alguns pensadores contemporâneos como, por exemplo, o sociólogo italiano Domenico De Massi, fantasia e realidade são elementos fundamentais à criatividade em qualquer ramo do conhecimento humano. Será ético abandonarmos a Terra após termos degradado seus ecossistemas e investirmos na cosmomigração, isto é, migração da Terra para outros planetas habitáveis? Isso parece ficção, mas a ideia de turismo espacial tem sido assunto de alguns meios de comunicação, inclusive em algumas revistas semanais de grande circulação como, por exemplo, foi matéria de capa da Época. Independentemente da exploração ficcional acerca do turismo no espaço sideral, os investimentos em pesquisas espaciais têm evoluído desde as explosões das bombas atômicas sobre Hiroshima e Nagasaki em agosto de 1945.

Historicamente os pensadores quando desejaram expressar novas ideias, novos paradigmas, recorreram a neologismos ou novas palavras. A Geoética, aqui sendo proposta de modo introdutório, pretende colocar a Terra como paradigma de ética ambiental. Vista do espaço "a Terra é azul”, expressou o cosmonauta russo Yuri Gagarin, o primeiro ser humano a avistar a Terra flutuando no espaço, em 12 de abril de 1961.

A palavra Geografia deriva dos termos gregos "geo" (terra) e "grafia" (estudo). Ética, por sua vez, também deriva de um termo grego "ethos" que significa caráter, modo de ser. Sócrates (470 - 399 a.C), filósofo da Grécia antiga, preconizou a frase "Conhece-te a ti mesmo". Ao longo da história a civilização humana acumulou vasto conhecimento sobre a Terra e o Universo, mas ainda há muito que conhecer sobre o Geo UERJ - Ano 14, nº 23 , v. 2, $2^{\circ}$ semestre de 2012 p. 479-508 ISSN: 1415-7543 E-ISSN: 1981-9021 http://www.e-publicacoes.uerj.br/index.php/geouerj 
cérebro e a mente humana. Contudo, a medicina revela que a composição bioquímica do corpo humano contém elementos semelhantes aos que compõe o solo.

No cenário internacional o relatório Jacques Delors, da UNESCO, sobre a educação para o século XXI, inicia o preâmbulo com o título "Educação ou a utopia necessária”. A meu ver, utopia tem a ver profundamente com ética, que tem a ver com amor à sabedoria, ou filosofia, que tem a ver com a capacidade humana de questionar e, especialmente, de pensar sobre o futuro, sobre o amanhã. Ora, a lei de conservação é natural até mesmo entre os animais irracionais. Navegando num "oceano de incerteza", com sugere Morin (2005), o ser humano carece e ainda tem algumas "ilhas de certeza". E essas ilhas não seriam alguns princípios e valores éticos?

É verdade que no reino hominal ainda existe, por um lado, muita ignorância e, por outro, nossas verdades são relativas, afinal perfeição - assim como não ter necessidade - é algo divino. Mas a consciência moral livre do ser humano possibilita-o pensar, usar a razão e exercitar a liberdade no ato de escolha.

Para além de todas as necessidades humanas, que podem variar conforme as culturas e classes sociais, a necessidade básica de viver neste corpo celeste chamado Terra, a meu ver, ainda é o que nos coloca na mesma condição humana de terráqueos. Poder-se-ia objetar que os ricos são mais iguais que os outros, ou que os ricos tem mais acesso à água limpa. Mas até quando? O instinto de conservação da própria vida de toda espécie do reino hominal colocar-nos-ia em condição primitiva, ou próxima dos animais inumanos. Nessa hipotética condição os "ricos de pote cheio" seriam minorias ou pequenas presas diante da maioria de leões famintos.

$\mathrm{Na}$ cadeia alimentar no reino animal existe certo equilíbrio. Algo que entre nós humanos já atingiu o desequilíbrio extremo. Ou será que dois terços da população mundial vivendo na miséria seria normal? Parece-nos, portanto, que carecemos resgatar alguns princípios éticos universais como estímulo ao fomento de ações políticas desde a escala local até a global como valorização do direito essencial à vida. E isso implica em nos dispormos ao novo. Nesse sentido, propomos o que poderemos chamar de geoética, ou uma Ética da e para a Terra.

Pensar, viver, analisar a cidade, o mundo a partir do olhar da geoética pressupõe

Geo UERJ - Ano 14, nº 23 , v. 2, $2^{\circ}$ semestre de 2012 p. 479-508

ISSN: 1415-7543 E-ISSN: 1981-9021

http://www.e-publicacoes.uerj.br/index.php/geouerj 
um esforço reflexivo que busca integrar saberes originados a partir da Física Quântica (CAPRA, 1984) como o principio da incerteza e da complementaridade, que abriram caminho para a Teoria da Complexidade idealizada pelo pensador Edgar Morin (MORIN, 2005).

O clássico paradigma cartesiano do século XVII que fragmentou a dualidade corpo e alma, começa a entrar em crise no final do século XIX, e a crise se aprofundou a partir da década de 1930 com a revolução científica no começo do século XX (CAPRA, 1994). Novos horizontes se abrem para o olhar dos terráqueos, especialmente a partir das inesperadas descobertas da Física Quântica (GOSWAMI, 2006).

A partir desses fundamentos científicos, podemos começar a refletir sobre a cidade a partir de um complexo olhar geográfico para o mundo. É o que ousamos em criatividade filosófica na Geografia, sugerindo a Geoética.

Geoética é uma mistura de razão e emoção, uma complementaridade entre matéria e espírito. É pensar o futuro a partir da metamorfose do presente. É estar com os pés na Terra e a cabeça no Universo. É admitir que somos humanos (terráqueos), sem distinção de nacionalidade, idioma, cor, etnia, sexo ou classe social.

Geoética é a Ética da Terra. É admitir que nós humanos, terráqueos, somos filhos e filhas da Terra. É aceitar que somos solo, nascidos do barro, feitos de húmus, da Terra. A Geoética nos coloca materialmente e espiritualmente junto à Terra. A ética da Terra nos faz refletir sobre algo óbvio, mas que precisa ser dito, lembrado ou relembrado. Afinal, nossos corpos de humanos terráqueos são constituídos, bioquimicamente, dos mesmos elementos que compõe o solo, a terra, o barro. As águas de nossos corpos possuem os mesmos elementos bioquímicos das águas dos oceanos; basta provarmos o gosto salgado de nossas lágrimas ou suor.

Assim, a Geoética nos ensina que não existe dicotomia entre a Terra e a Ética, separação entre Terra e Humanidade. Tudo que utilizamos, computadores, automóveis, roupas, alimentos, enfim, tudo tem sua gênese na Terra.

Se não formos cremados, quando as nossas pernas não puderam mais aguentar nos carregar, nossos corpos serão enterrados na terra. Lá em baixo, nas covas, nossos corpos nutrirão a Terra, o solo.

Em geografia da população analisa-se, entre outros aspectos, as taxas de

Geo UERJ - Ano 14, no. 23, v. 2, $2^{\circ}$ semestre de 2012 p. 479-508 ISSN: 1415-7543 E-ISSN: 1981-9021

http://www.e-publicacoes.uerj.br/index.php/geouerj 
mortalidade, mas não se discute a morte. Afinal, quem não tem medo da morte? É verdade, mas a Geoética nos convida a refletir sobre a vida e a morte neste orbe terrestre. É preciso pensar sobre esta verdade biofísica, isto é, sobre a morte do corpo. Talvez alguns não queiram nem mesmo pensar na morte, porém, pensadores contemporâneos o fazem com certa tranquilidade como, por exemplo, Edgar Morin, o fez em 1956 na obra “O homem e a morte”. (BURGUIÈRE, 2008)

Para aqueles que se dizem materialistas, niilistas, a morte seria o fim, o nada, um sono eterno. Mas outros podem preferir considerar a morte apenas como uma transformação do corpo, uma mutação psico-biofísica, uma viagem para a quinta ou sexta dimensão do espaço-tempo. Foi isso que a descoberta de Albert Einstein, em 1905, revelou: outras dimensões espaço-tempo para além da terceira dimensão do visível. Mais tarde, na década de 1930, a Física Quântica nos trouxe outras descobertas inovadoras: nossos corpos se constituem de milhões de partículas subatômicas, de tal modo que existem inúmeros "espaços" vazios (não-localidade quântica) na estrutura biofísica de nossos corpos. Recentemente os físicos descobriram o bóson de Higgs, ou a "partícula de Deus".

Certamente essas descobertas científicas possibilitam enorme aproximação entre a física e a metafísica, entre ciência e espiritualidade, como sugere o físico Fritjof Capra na obra "O Tao da Física". Outro renomado físico, Amit Goswami, professor titular da Universidade de Física de Oregon (EUA) também se destaca como pesquisador que busca conciliar a física quântica com a espiritualidade na obra "A Física da Alma" (GOSWAMI, 2006).

Independente das crenças religiosas, do ponto de vista científico da nova Física o conceito de não-localidade quântica se aproxima de uma concepção filosófica acerca da Ética, cujos princípios filosóficos universais - verdade, ação correta, paz, amor e nãoviolência - ampliam-se em inúmeros valores éticos responsabilizando cada indivíduo para com a (re)construção de um outro mundo possível aqui na Terra. Nesse sentido, somos herdeiros do passado, mas criadores do futuro que se inicia hoje, todos os dias, enquanto houver sol.

Mas o que tem a ver o conceito de não-localidade quântica com a Geoética? Milhões de pessoas da cultura Oriental (budistas, hindus e outros) influenciam na 
cultural Ocidental possibilitando a mutação filosófica entre essas duas civilizações.

Se entre os ocidentais admite-se o mito do eterno retorno (ELIADE, 1988), entre budistas e hindus esse mito tem outra denominação que contribui para uma diferente visão da relação homem-natureza que perpassa pela transcendência e corrobora para uma "ética ambiental". Vejamos as palavras do físico Goswami (2006, p.244):

\begin{abstract}
Primeiro, o pensamento reencarnatório pode ser de grande valia para que as pessoas comuns vejam o valor da ética em suas vidas. Nas sociedades materialistas, a ética é considerada relativa; isso corrói a moralidade, a legalidade não consegue ocupar o papel da moralidade com a velocidade desejada, e as sociedades degeneram, como vemos hoje com frequência. Porém, se as pessoas sabem que a transgressão ética desta vida conduz a repercussões cármicas na próxima, a ética se torna importante. (...) Por último, mas não menos importante, a teoria da reencarnação nos diz que voltamos à Terra em cada encarnação para realizar algum trabalho significativo, para aprender alguns contextos e remover algum carma negativo. Em outras palavras, temos um destino a cumprir.
\end{abstract}

$\mathrm{O}$ século $\mathrm{XX}$, com as grandes Guerras mundiais, morreu. E com ele também morreram muitos preconceitos, ideologias, totalitarismos e ditadores (Lenin, Stálin, Hitler, Mao, Médici, etc). Mas nesse mesmo século, movimentos sociais da juventude brotaram com a esperança, a utopia, o sonho de um mundo ecologicamente saudável.

Em 1968 a juventude de novos terráqueos gritou, cantou e escreveu poesias para um mundo novo. Na Europa, por exemplo, aquela juventude semeou ideias que contribuíram para a invenção dos Partidos Verdes almejando fundar uma nova visão social que poderíamos chamar de EcoPolítica e aqui vale lembra a contribuição do geógrafo Carlos Walter (GONÇALVES, 1989).

Simbolicamente entendemos que a Terra está grávida de uma nova geração, de uma nova humanidade que ama a Terra, que não tem medo nem preconceito de dialogar acerca de ciência e espiritualidade. A meu ver, estamos em pleno processo de gestação de uma nova humanidade, de uma nova mentalidade fundamentada na educação do futuro. A necessária reforma do pensamento humano, como sugere o filósofo Edgar Morin (2005), a reforma dos espíritos, de nós humanos, a nosso ver, está em pleno processo de gestação.

Esse processo de mutação, embora aparentemente paradoxal, também vem sendo favorecido pela globalização, como sugere Milton Santos (2002, p. 174). Em suas palavras:

Agora que estamos descobrindo o sentido de nossa presença no planeta,

Geo UERJ - Ano 14, no. 23, v. 2, $2^{\circ}$ semestre de 2012 p. 479-508

ISSN: 1415-7543 E-ISSN: 1981-9021

http://www.e-publicacoes.uerj.br/index.php/geouerj 
pode-se dizer que uma história universal verdadeiramente humana está, finalmente, começando. (...) Muito falamos hoje nos progressos e nas promessas da engenharia genética, que conduziriam a uma mutação do homem biológico, algo que ainda é do domínio da história da ciência e da técnica. Pouco, no entanto, se fala das condições, também hoje presentes, que podem assegurar uma mutação filosófica do homem, capaz de atribuir um novo sentido à existência de cada pessoa e, também, do planeta.

As mutações tecnológica e filosófica humana, como sinaliza o geógrafo Milton Santos (2002), na obra "Por uma Outra Globalização", vem se tornando, gradativamente, a passos lentos, uma realidade planetária. Essa mutação não tem prazo, mas parece ser irreversível. É um novo mundo que nós humanos estamos construindo lentamente.

A Terra, a Geo, em grego, também chamada de Gaia, deusa grega, pelo climatologista James Lovelock (1996), pode ser considerada como um organismo vivo. A Geo pulsa vida, as mais complexas formas de vida que integram todos os reinos da natureza: mineral, vegetal e animal. Não existe vida apenas material. Toda forma de vida, na essência, é espiritual. A máxima filosófica de René Descarte, "Penso, logo existo", que pressupunha a separação entre corpo e alma, ou entre matéria e espírito, foi um equivoco filosófico. $\mathrm{Na}$ verdade, hoje sabemos, não existe dicotomia, separação entre matéria e espírito. Existe sim, integração, complementaridade. Assim a vida é um complexo biofisico-psico-sócio-cultural, nós humanos somos Homo Complexus (MORIN, 2005).

A Geoética, assim, resgata o ethos da Terra, o caráter, o modo de ser terráqueo humano na Terra. Podemos, nessa concepção complexa, dizer que a Geoética sopra, respira e inspira o espírito da Terra. De forma simbólica podemos dizer que, doravante, todos os terráqueos necessitam semear a geoética, religar a alma humana ao espírito da Terra.

Podemos até considerar que, de certo modo, a essência da Geoética estaria, inconscientemente ou implicitamente, embutida em muitas ações ambientalistas, nesse processo histórico de consciência ambiental, mas também na busca crescente pela implantação dos sistemas de gestão ambiental (SGA), que vem paulatinamente se constituindo em um novo paradigma de administração nas empresas, nos acordos ambientais internacionais, no direito ambiental em evolução na medida em que ocorre o progresso moral da sociedade. Enfim, busca-se a ética para nortear a crise ambiental.

Geo UERJ - Ano 14, nº 23 , v. 2, $2^{\circ}$ semestre de 2012 p. $479-508$

ISSN: 1415-7543 E-ISSN: 1981-9021

http://www.e-publicacoes.uerj.br/index.php/geouerj 
Contudo, o desafio é enorme, histórico, porém, pensamos que o debate e a reflexão sobre a geoética se faz necessária para a "reforma do pensamento" (MORIN, 2005), reforma da política, da democracia. A nosso ver, portanto, a Geoética está no caminho da Educação do futuro.

A Geoética é a fusão de Ciência com Ética. Na medida em que o ser humano se liberta dos dogmas das religiões, isto é, das ideologias das igrejas, ele assume o governo de sua espiritualidade inerente ao humano. Essa espiritualidade humana independe de ser ou não religioso, de pertencer ou não a uma igreja. Ateus, agnósticos, islâmicos, hindus, budistas, cristãos, enfim todos os seres humanos possuem espiritualidade. Esse patrimônio, a espiritualidade, pertence a cada indivíduo e, portanto, pode e deve ser governado soberanamente por cada ser humano.

Nesse sentido, a Geoética concebe a Terra como sendo o único "templo" que une, acolhe, recepciona, congrega, aproxima todos os seres humanos, todos os filhos e filhas da Terra. Mas não existe nenhum homem ou mulher que detenha nenhuma verdade absoluta. A manutenção, ou melhor, a sustentabilidade desse templo depende do apoio mútuo entre os seres humanos.

O processo de construção do "Reino da Geoética" com base no apoio mútuo não se dará a partir da hegemonia da "moral de senhor" sobre a "moral de escravo". Nesse processo não existem "super-homens", mas existem homens e mulheres com a mesma essência de complexidade biofísico-psico-sócio-cultural, isto é, somos Homo complexus (MORIN, 2005).

\section{Considerações finais}

O resultado desta reflexão nos leva a concluir provisoriamente que o embate teórico-prático, de um lado, a defesa da segurança ambiental como garantia em longo prazo dos recursos naturais essenciais à reprodução da vida na Terra e, de outro, o realismo político na defesa dos interesses (nacionais, empresariais e individuais) no imediatismo da lógica capitalista não se esgotou na práxis social. Foi o que tentamos demonstrar neste artigo.

Por sua vez, o paradoxo acima - segurança ambiental versus realismo político não exclui a utopia por uma Terra sócio-ambientalmente sustentável. Ao contrário, se

Geo UERJ - Ano 14, no. 23, v. 2, $2^{\circ}$ semestre de 2012 p. 479-508 ISSN: 1415-7543 E-ISSN: 1981-9021

http://www.e-publicacoes.uerj.br/index.php/geouerj 
faz necessário o engajamento com utopia como gestação do novo, da busca pela reforma do pensamento (MORIN, 2005) e a crença política da capacidade dos humanos construírem caminhos societários alternativos fundamentados em novas epistemologias e ontologias que se fundamentem na razão e na emoção, na ciência e na ética, enfim, na solidariedade e cooperação entre as coletividades humanas na escala geográfica local, nacional e internacional. Foi o que sinalizamos na reflexão acerca da geoética do apoio mútuo.

Esse processo, porém, não exclui os conflitos inerentes à nossa natureza humana, à essência do Homo-complexus que sente amor e ódio, que tem razão e intuição, riso e choro, egoísmo e altruísmo, sabedoria e loucura (MORIN, 2005). Contudo, ao se admitir as limitações dos humanos e, ao mesmo tempo, a capacidade de criatividade, inventividade e superação individual e coletiva sobre os desafios da vida em sociedade, pode-se olhar para o futuro que se engendra a partir do cotidiano com otimismo crítico, isto é, realismo e utopia.

Finalizando, é necessário deixar sempre a mente aberta para novas ideias que apontem para a manutenção da utopia de construção de um outro mundo possível. Há duzentos anos pensar na liberdade civil dos negros no Brasil seria motivo de gargalhadas sarcásticas. "Pobre ingenuidade", diriam naquele tempo. Falar dos direitos das aves e das plantas certamente seria uma utopia, pelo menos até a metade do século XX. Pensamos que vale à pena refletir a respeito do significado da palavra utopia como gestação do novo (SANTOS,1996). O que ainda não existe materialmente, não significa que seja algo impossível, irrealizável.

A utopia, porém, não nos isenta do purgatório da critica pela qual este texto terá que passar. É preciso manter acessa a razão crítica, porém, com otimismo. Diríamos que só não é possível algo que não existe em nosso pensamento, por isso estamos pensando na construção da geoética do apoio mútuo como contribuição para a paz nas relações entre os humanos e nas relações internacionais.

\section{REFERÊNCIAS}

ARISTÓTELES. Ética a Nicômano. São Paulo: Martins Claret, 2007.

Geo UERJ - Ano 14, nº 23 , v. 2, $2^{\circ}$ semestre de 2012 p. 479-508

ISSN: 1415-7543 E-ISSN: 1981-9021

http://www.e-publicacoes.uerj.br/index.php/geouerj 
BOFF, Leonardo. Ecologia, Mundialização, Espiritualidade. 2a ed. São Paulo: Ática, 1996.

BORNHEIM, Gerd. Os Filósofos Pré-Socráticos. São Paulo: Cultrix, 1985.

BURGUIÈRE, André. A longa viagem de "O homem e a morte". IN: PENA-VEGA, Alfredo \& LAPIERRE, Nicole (org). Edgar Morin em Foco. São Paulo: Cortez, 2008, p. 69-98.

CANO, Javier S. De la seguridad compartida a la seguridad ecológica. Barcelona: Icaria, v. 15, 1998.

CAPRA, Fritjof. O Tao da Física. São Paulo: Cultrix, 1984. O Ponto de Mutação. São Paulo: Cultrix, 1994.

CASTORIADIS, C. \& COHN-BENDIT, D. Da Ecologia à Autonomia. São Paulo: Brasiliense, 1983.

DELORS, Jacques. Educação: um tesouro a descobrir. $10^{\mathrm{a}}$ ed. São Paulo: Cortez/Unesco, 2005

ELIADE, Mircea. O Mito do Eterno Retorno: Arquétipos e repetição. Lisboa: Ed. 70, 1988.

GARCIA-TORNEL, Francisco C. Sociedades y territorios en riesgo. Barcelona: Serbal, 2001.

GONÇALVES, C.W.P. Os (Des)Caminhos do Meio Ambiente. São Paulo: Contexto, 1989.

GOSWAMI. Amit. A Física da Alma. 4ª ed. São Paulo: Aleph, 2006.

GUATTARI, Felix. As três ecologias. Campinas: Papirus, 1993.

HOSSNE, Willian Saad. Ética, Saúde e Biotecnologias. IN: MIRANDA, Danilo S.

Ética e Cultura. São Paulo: Perspectiva, 2004, p. 185-205.

KROPOTKIN, Piotr. La seleccion natural Y El Apoyo Mutuo. Madrid: C.S.I.C., 2009.

LEFF, Enrique. Saber Ambiental. Petrópolis: Vozes, 2001.

LE PRESTE, Philippe. Ecologia Internacional. São Paulo: Senac, 2003.

LOVELOCK, James. Gaia. A prática científica da medicina planetária. Lisboa: Instituto Piaget, 1996.

MAQUIAVEL, N. O Príncipe. Porto Alegre: L\&PM, 1998.

MORGENTHAU, Hans. A Política entre as Nações - a luta pelo poder e pela paz.

Geo UERJ - Ano 14, nº. 23, v. 2, $2^{\circ}$ semestre de 2012 p. $479-508$

ISSN: 1415-7543 E-ISSN: 1981-9021

http://www.e-publicacoes.uerj.br/index.php/geouerj 
Brasília: UnB/Funag/IPRI, 2003.

MORIN, Edgar. Os Sete Saberes necessários à Educação do Futuro. 10ª ed. São Paulo: Cortez/Unesco, 2005.

ONU. Aliança de Civilizações: o Fórum do Rio de Janeiro. Brasília: Funag, 2011.

RIBEIRO, Wagner C. A Ordem Ambiental Internacional. São Paulo: Contexto, 2001. Geografia Política da Água. São Paulo: Annablume, 2008.

SANTOS, Boaventura de S. Pela Mão de Alice: O Social e o Político na PósModernidade. 12ª ed. São Paulo: Cortez, 1996.

SANTOS, Milton. Por uma Outra Globalização. $9^{\text {a }}$ ed. São Paulo: Record, 2002.

SARFATI, Gilberto. Teoria de Relações Internacionais. São Paulo: Saraiva, 2005.

SHIVA, Vandana. Monoculturas da mente. São Paulo: Gaia, 2003.

VESENTINI, J.William. Geografia, Natureza e Sociedade. São Paulo: Contexto, 1989.

WALTZ, Kenneth N. O Homem, o Estado e a Guerra. São Paulo: Martins Fontes, 2004.

\footnotetext{
${ }^{\mathrm{i}}$ Essa reflexão acerca do embate entre segurança ambiental e realismo político teve como ponto de partida nosso trabalho de conclusão do curso/disciplina de pós-graduação "Geografia Política e Meio Ambiente" ministrado pelo Prof. Dr. Wagner Costa Ribeiro, no Departamento de Geografia da USP.

Artigo encaminhado para publicação em setembro de 2012.

Artigo aceito para publicação em novembro de 2012.
}

Geo UERJ - Ano 14, nº. 23, v. 2, $2^{\circ}$ semestre de 2012 p. 479-508

ISSN: 1415-7543 E-ISSN: 1981-9021

http://www.e-publicacoes.uerj.br/index.php/geouerj 